\title{
Hannocourt - Viviers
}

La Lèche et Mercière, projet d'étang

\section{Gilles Mangin}

\section{(2) OpenEdition}

Journals

Édition électronique

URL : http://journals.openedition.org/adlfi/8863

ISSN : 2114-0502

Éditeur

Ministère de la culture

Référence électronique

Gilles Mangin, « Hannocourt - Viviers », ADLFI. Archéologie de la France - Informations [En ligne],

Lorraine, mis en ligne le 01 mars 2001, consulté le 21 avril 2019. URL : http://journals.openedition.org/ adlfi/8863

Ce document a été généré automatiquement le 21 avril 2019

(C) Ministère de la Culture et de la Communication, CNRS 


\title{
Hannocourt - Viviers
}

\author{
La Lèche et Mercière, projet d'étang
}

\section{Gilles Mangin}

Identifiant de l'opération archéologique : F1357200100051

Date de l'opération : 2001 (EV)

1 Un projet d'étang, portant sur une surface de 5 ha environ, a été précédé de sondages archéologiques préventifs. Le terrain, présentant une très faible couverture pédologique ( $0,05 \mathrm{~m}$ de terre végétale puis de l'argile), n'a livré aucun indice archéologique sur l'ensemble de l'emprise.

INDEX

Index géographique : Lorraine, Moselle (57), Hannocourt operation Fouille d'évaluation (EV)

\section{AUTEURS}

GILLES MANGIN

AFAN 